\title{
Contents: Research for All 5 (1)
}

Editorial: Achieving and demonstrating innovation and new learning in public engagement

Sandy Oliver and Sophie Duncan

\section{SPECIAL FEATURE}

Supporting small and medium-sized enterprises in the educational technology sector to become more research-minded: Introduction to a small collection

Alison Clark-Wilson, Anissa Moeini, Kusha Anand, Canan Blake, Mutlu Cukurova, Santiago De Ossorno Garcia, Kim Issroff, Rose Luckin, Tunde Olatunj,

Laura Outhwaite and Kristen Weatherby

What inspired my thinking to create UCL EDUCATE?

Rose Luckin

The mentoring relation as an interpersonal process in EDUCATE:

A qualitative case study of mentor-mentee perspectives

Santiago De Ossorno Garcia and Luke Doyle

Pre-emptive intervention and its effect on student attainment and retention

Murray Morrison, Canan Blake, Fraser Embleton-Smith, Jan Gosiewski

and Jonathan Zvesper

Developing Little Bridge as an evidence-informed English language learning platform for 6-12 year olds

Emma Rogers and Kristen Weatherby

\section{GENERAL ARTICLES}

Going beyond the one-off: How can STEM engagement programmes with young people have real lasting impact?

Martin Archer, Jennifer DeWitt, Carol Davenport, Olivia Keenan, Lorraine Coghill, Anna Christodoulou, Samantha Durbin, Heather Campbell and Lewis Hou

Development of the School Science Club at Cardiff University

James Blaxland, Rhys Thomas and Les Baillie

A learning architecture: Developing a collective design pedagogy

in Mumbai with Muktangan School children and the Mariamma Nagar

community

Nicola Antaki

Creating impact through participatory action research: A film festival framework case study

Ruth Farrar

The Future of Our Seas: Marine scientists and creative professionals collaborate for science communication

Laurence De Clippele, Madlaina Michelotti, Charlotte R. Findlay, Amy Cartwright, Qing Fang, Charlie Wheatley, Ashleigh Sladen, Kes Scott-Somme, Harry R. Harding, Juliette Jackson, Laura E. Hepburn, Jessica Giannotti, Grace Carroll, Nicole Heidtke, Alison M. Worrall and Kris De Meyer

This is an open-access journal distributed under the terms of the Creative Commons Attribution Licence (CC-BY) $4.0 \mathrm{https}: / /$ creativecommons.org/licenses/by/4.0/, which permits unrestricted use, distribution and reproduction in any medium, provided the original author and source are credited. https://doi.org/10.14324/RFA.05.1.00. (ISSN 2399-8121). https://www.uclpress.co.uk/pages/research-for-all 
Co-researching complexities: Learning strategies for edge walking in community-university research partnerships

Laura A. Chubb, Christa B. Fouché and Karen Sadeh Kengah

Turning 'evidence for development' on its head: A view from Africa

174

Ruth Stewart 